\title{
Widyaiswara's Role in Apparatus Development in the Pandemic and New Normal Era
}

\author{
Ita Hartati ${ }^{1}$, Azwar Iskandar ${ }^{2}$ \\ ${ }^{I}$ Pusdiklat Pengembangan Sumber Daya Manusia, BPPK, Kementerian Keuangan, Indonesia \\ ${ }^{2}$ Master Program in Public Administration, Open University, Indonesia \\ hartati.ita@gmail.com,azwar.iskandar@gmail.com
}

\begin{abstract}
This research aims to provide an overview of the challenges and role of Widyaiswara in the Ministry of Finance in improving ASN competence through adaptation and innovation in the pandemic and new normal era. Using a qualitative descriptive approach, this study found that widyaiswara is required to be able to think creatively and innovatively. The challenge is whether widyaiswara is able to make interesting multimedia teaching materials. Widyaiswara was challenged and required to continue to improve and change. Widyaiswara should be able to utilize technology to open the horizon of thinking and view technology as an opportunity to improve ASN competence in the future. To answer the challenges and demands of change in this pandemic and new normal era, widyaiswara can act as facilitator, motivator, inspiration, innovator, dynamicator and role model through innovation and adaptation in the pandemic era and new normal through its roles in aspects of bureaucracy efficiency, digital literacy, agile organization mindset, public service responsiveness, and integrated and flexible working space.
\end{abstract}

\author{
Keywords \\ Wdyaiswara; challenge; role; \\ pandemic, newnormal

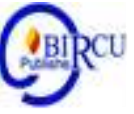

\section{Introduction}

The policy on reforming the work system of the State Civil Apparatus (Aparatur Sipil Negara, ASN) in Indonesia has actually been prepared gradually, long before a new order (new normal) emerged (LAN, 2020). The existence of corona virus disease (COVID19) pandemic, requires the addition of health protocols in the working system (Ahmed et. al, 2020; Adhikari, et. al., 2020). As a consequence, it needs to be anticipated quickly, arrangements on flexible working arrangements, adjustment of human resource management, and implementation of health protocols and improvement of infrastructure support (Carnevale and Hatak, 2020; AM. et. al, 2020; Jooss, McDonnell and Conroy, 2020).

In this regard, the State Administration Agency (Lembaga Administrasi Negara, LAN) seeks to continue to make efforts to improve the competence of ASN so that it can work quickly, responsively, courageously in making decisions, and always looking for new breakthroughs. The policy issued in circular letter (Surat Edaran, SE) of the Minister of Administrative and Bureaucratic Reform (Menpan-RB) Number 58/220 concerning the Work System of ASN Employees in the New Normal Order provides an opportunity for ASN to adjust its work system. This is to maintain the continuity of the implementation of duties and functions in the implementation of productive and safe government and public services from the COVID-19 virus (LAN, 2020).

As is known, the impact of the COVID-19 pandemic is very multidimensional, including in government (Balanzá-Martínez, et. al., 2021). Therefore, a strategy is needed to implement the transformation of governance in terms of public services in the new 
normal system. Strengthening and utilizing information technology in order to accelerate the transformation of government administration needs to be done, one of which is by reforming services that were originally carried out face-to-face transforming into online services (Sulaksono, Astuti and Almusadieq, 2020). The COVID-19 pandemic has become a more complex challenge for state management as well as a golden momentum in redesigning asn competency development strategy. Several strategic steps to realize a superior ASN, such as by changing the patterns of competency development that are classical to innovative patterns such as through blended learning, distance learning, and elearning into an inevitable demand (LAN, 2020).

In carrying out its duties and functions, namely managing education, training (learning), certification and knowledge management in the field of state finance, the Financial Education and Training Agency (Badan Pendidikan dan Pelatihan Keuangan, BPPK) as one of the implementers (assistants) of the Minister of Finance, continues to carry out health protocols and continues to innovate and adapt to services provided in the emergency of the COVID-19 pandemic. This is in line with the direction of the Minister of Finance who stated that performance targets on a learning and growth perspective as a service area of BPPK should not be any change or decrease in performance targets. Therefore, BPPK does not stop services due to pandemic conditions, but adapts or converts services by optimizing digital platforms (BPPK, 2020). Various studies predict that the future of government will experience disruptions in all sectors, strengthening artificial intelligence, the use of big data and online service interactions.

Optimization of digital services is actually not new. Since 2017, several policies have been established such as PER-5/PP/2017 on Learning Evaluation, PER-4/PP/2017 concerning Learning Design, PER-8/ PP/2017 concerning learning through microlearning, PER-2/PP/2018 concerning learning through e-learning, and PMK 45/ PMK.011/2018 concerning Learning Needs Analysis, has provided initial capital for BPPK to adapt in this pandemic period, namely by encouraging innovative digital-based learning services, especially through the Kemenkeu Learning Center (KLC) platform. With the outbreak of the pandemic that requires human resources (HR) of the Ministry of Finance (Kemenkeu) to run work from home, learning through digital platforms is now encouraged to be more massive in its utilization, where BPPK is expected to be able to create and deliver new model learnings in accordance with current conditions (BPPK, 2020).

As a form of adaptation to technological developments, flexibility learning space, consideration of effectiveness and efficiency, ease of application of integrated learning, BPPK develops learning in the form of distance training as an alternative to learning in the BPPK environment. Distance Learning which is then abbreviated as Pelatihan Jarak Jauh (PJJ) is a learning process that is carried out outside the training venue that emphasizes on self-learning that is managed systematically and not limited by distance and time by using various learning media (Iskandar and Subekan, 2020). Online learning or distance learning aims to meet the needs of improving and developing human resources in the Ministry of Finance through the use of technology and information despite being constrained by restrictions on the implementation of training such as in the current pandemic.

As mentioned above, PJJ in BPPK environment is implemented through a web-based KLC system (www.klc.kemenkeu.go.id) for Non-Face-to-Face sessions and Virtual Meeting Zoom applications or others for Face-to-Face sessions as well as Google Form applications and others for training sessions, assignments, and exams (evaluation). This PJJ model is a merger of synchronous and asynchronous learning models. This synchronous model in PJJ is done through Zoom Virtual Meeting application where trainees and teachers/instructors interact simultaneously through the application (Narayana, 2016; 
Iskandar \&Subekan, 2020). While the asynchronous model in PJJ is done through the KLC system where learning is centered on trainees with an approach to self-learning through the utilization of online learning resources required in the system (Iskandar and Subekan, 2020; Chen, Sun and Jin, 2019).

Widyaiswara as a functional position that has the task of education, teaching, training, training evaluation and training development is required to play a role in the improvement of ASN competencies that include knowledge, attitude and skills through an effective and efficient learning process, especially in the pandemic and new normal (Gunawan, Sasongko and Kristiawan, 2021; Hasyim, 2018). It is through this learning process that transfer and transform knowledge that has implications for behavior changes. However, in a pandemic and new normal atmosphere, organizing training activities that prioritize the synergy of all components in the learning process will get a tremendous challenge. One of them is the adaptation of widyaiswara role in learning activities that must still prioritize the quality of teaching despite the limitations of the education process, teaching and training (Dikjartih) in a pandemic and new normal atmosphere that must prioritize health protocols. Widyaiswara within the Ministry of Finance is required to provide its best role in improving ASN competence through adaptation and innovation in the pandemic and new normal atmosphere.

In the implementation of his duties, widyaiswara is required to have good competence in his field and has a very important role in realizing the quality of learning in a training. In pandemic and new normal conditions, this quality of learning is difficult to obtain to the maximum. Therefore, widyaiswara's role in the development of ASN competency to be more qualified and competent is needed. This pandemic and new normal era, in which every joint of life should be locked down in an effort to reduce the spread of COVID-19, presents its own challenges to the role of widyaiswara in delivering learning to ASN. This is then coupled with the demands of flexible work arrangements that force each ASN to reduce physical interaction in the work environment. The government's vision to create a world-class bureaucracy becomes increasingly uneasy and challenging because the characteristics of the Indonesian bureaucracy are often careless, working routinely, the existence of sectoral egos and closed makes flexible work arrangement efforts feel will further hinder the achievement of the government's vision. Therefore, the increasing role of widyaiswara is needed in dealing with future bureaucratic problems in the current pandemic and new normal atmosphere.

Departing from the description, the problems that will be answered in this study are: (1) how must the challenges faced by widyaiswara in carrying out its role in the development of ASN competencies?; (2) What is the role of widyaiswara in the era of pendemi and new normal? To answer the above problems, this scientific paper aims to provide an overview of the challenges and role of Widyaiswara within the Ministry of Finance in improving asn competence through adaptation and innovation in the pandemic and new normal atmosphere.

\section{Resarch Methods}

Based on the objectives to be achieved, the writing of this scientific work falls into the category of descriptive research that aims to describe certain situations or symptoms in detail (Hamdi and Ismaryati, 2019). In terms of approach, this study uses qualitative approach through library study and observation (John, 2013; Sarwono, 2006). The data sources used is secondary data obtained from several sources such as regulations related to learning and development of apparatus resources or ASN, Program Reference Framework 
Training, Outlines of Learning Programs, results of Needs Training Identification, and Training Organizing Report.

\section{Results and Discussion}

\subsection{Widyaiswara's Challenge in the Pandemic and New Normal Era}

The COVID-19 pandemic has impacted many aspects of human life. Not only impacting business activities, the COVID-19 pandemic also has an impact on the competency development model of ASN or Civil Servants (PNS) especially in the training path. In LAN Regulation No. 10 of 2018, it is mentioned that ASN competency development is an effort in meeting the competency needs of civil servants with standards of position competency and career development plan. The development of bureaucratic apparatus resources is an integral part of increasing the bureaucratic apparatus's qualifications following the community's demands (Salam, 2021). In order to carry out these efforts, online training becomes an option in pandemic and new normal times such as today. The COVID-19 pandemic is demanding that everyone keep their distance in accordance with health protocols. As a consequence of this, online training is a solution for almost all training institutions, especially for ASN.

The fundamental question that is questionable in the face of this condition is how readiness of training institutions in organizing this virtual-based training? Of course, not all training institutions in the government environment are ready to conduct online training in a mature manner. Furthermore, what about the readiness of human resources owned, both as organizers, managers, especially trainers/widyaiswara. Widyaiswara plays an important role in developing ASN competencies so that they must be able to educate and train ASN with constructive learning patterns in accordance with the development of the times and under any circumstances including during the COVID-19 pandemic. In online training, widyaiswara is required to prepare a variety of interesting learning media. In training conducted through distance learning, widyaiswara is required to be able to think creatively and innovatively. One of them is by preparing digital teaching materials based on information technology.

If in classical training widyaiswara only prepare learning media such as power point slides, films or short videos, discussion and evaluation materials, then in online training, widyaiswara is also required to be able to compose multimedia learning media. The challenge is whether widyaiswara is able to make interesting multimedia teaching materials. To create multimedia learning media, widyaiswara must be familiar with shooting, animation, screen recording and editing process that takes not a little time, not to mention knowledge and insights related to devices or virtual learning media used by the organizers, such as zoom application, google meet, webex meet, and others. It is not impossible, widyaiswara must be ready to host when the training officer/organizer is unable to guide the virtual face-to-face normally due to technical problems such as networking and others. Therefore, it is no exaggeration to say that the biggest challenge of online training is actually on the shoulders of widyaiswara so that to face these challenges, widyaiswara must be improved and changed.

In the current era of training, the burden is on widyaiswara's shoulders. Online training requires widyaiswara to change the ways and methods in facilitating its training classes. There is a new competency that must be initiated widyaiswara at this time, namely competence in making multimedia teaching materials.. But really, this is not a hard job considering the wide variety of tutorials making multimedia teaching materials available on the internet. Besides learning from tutorials, sharing knowledge between widyaiswara 
can also be a solution to overcome these challenges. In addition, widyaiswara needs to improve the ability to communicate through online media. Communication skills are a basic necessity for a widyaiswara. Delivering material virtually has its own challenges. Classically, participants can still not or do not understand the material presented.

Entering the new normal phase, widyaiswara as the spearhead of ASN competency development must abandon the old mindset, where learning is classical and procedural. This new normal order is characterized by a more flexible, dynamic, and agile bureaucracy. The agile bureaucratic ASN development model is characterized by needs driven learning. Trainees should be able to develop themselves according to their desired learning needs, wherever and whenever. This is where the importance for widyaiswara prepare digital-based teaching materials.

The use of smart power is also needed in the face of the new normal challenges today. Widyaiswara should be able to utilize technology to open the horizon of thinking and view technology as an opportunity to improve ASN competence in the future. Smart power is a way of developing ASN competencies that are more based on digital literacy. Widyaiswara should be able to process digital information and prepare it into a teaching material that can be accessed by various media such as through social media, podcasts, vlogger weblogs and others.

Once again, widyaiswara is expected to be able to think creatively, innovatively and entrepreneurally in preparing for the new normal order, and still perform to continuously strive to develop asn competencies. Widyaiswara is not expected to get caught up in the routine of the organization but is able to interpret every action as a form of major contribution to the changes of Indonesian civilization. Widyaiswara must understand well that the bureaucracy that exists today must be agile in the face of various national challenges that are at all times threatening. One of the actual things in the context of ASN is the change of bureaucratic reform, where it is not just a reform in the administrative sense but fundamentally that can change the way of work, mindset and mentality of bureaucracy.

As "teachers of the nation", widyaiswara, especially within the Ministry of Finance, is required to continue to develop itself to escort and guide the country to the challenges of the times through the development of superior and professional ASN competencies. This is very important considering the policy of the BPPK Strategic Plan of 2020-2025 related to learning models and methods that have established the need to optimize the implementation of digital learning for the country's financial human resources through the implementation of digital learning with a proportion of 50\% in 2020, 70\% in 2021-2023 and $80 \%$ in 2024. In the Plan also mentioned that BPPK will diversify learning methods using distance or digital as an alternative to face-to-face learning that is not limited to distance training, Open Class, Kemenkeu Corpu Talk, Open Access Course, Game Based Learning and others, digital learning ecosystem by adopting gamification in the learning system aligned with the performance system and reward system of the Ministry of Finance, quantity improvement (growth 20\%) and the causality of digital learning, and curation of external digital learning bppk (national / world class) relevant to the strategic needs of the Ministry of Finance to be integrated into the KLC platform.

\subsection{Widyaiswara's Role in the Pandemic and New Normal Era}

To answer the challenges and demands of change in the world of ASN, government bureaucracy and asn capacity building in this pandemic and new normal era, widyaiwara must be willing and able to change. Widyaiswara is a "nation teacher" who is required to be professional in managing classes, creating a fun learning atmosphere and can act as a 
facilitator, motivator, inspirator, innovator, dynamicator and role model through innovation and adaptation in the pandemic and new normal era. Therefore, in the face of the current conditions, widyaiswara (especially within the Ministry of Finance) can contribute through the following roles.

1. Bureaucratic Efficiency. To realize efficiency in the implementation of bureaucracy in Indonesia, widyaiswara must be the driving force to change the mindset of ASN that was previously ineffective to work, waste time, wasteful and less concerned (careless) with bureaucracy that serves the community in prime to be a fast, precise, effective and efficient ASN mindset in public servants, especially at new normal times such as today that demand people to have minimal physical activity.

2. Digital Literacy. The rapid development of the world today forces the whole community, including ASN to be able to adapt to technological advances. Industrial Revolution 4.0 that turned everything into the internet of things, making ASN must understand digital technology, so that the increase of digital literacy into the inevitability of today. Widyaiswara should be able to take a role as a facilitator and innovator in the development of this technology both in training and in ASN work activities so that the Indonesian nation can compete competitively with the international community, especially in the new normal era where information technology becomes the backbone in everything.

3. Agile Organization. Changes in the mindset of ASN which is still impressed to work on a routine, sectoral ego and closed and casual work, must be changed immediately. The world is running fast to move forward and change everything to be fast, simple, effective and efficient especially in the new normal era today. ASN that is still in the old mindset, will eventually be tergilas and considered useless. To prevent this, widyaiswara must act as motivator, inspiration, innovator and role model for ASN to change mindset in working faster, agile and innovative with the main goal of excellent service for all communities and the progress of the nation (Jarkasih, 2021).

4. Public Service Responsiveness. ASN as a public servant in this new normal era must work and act in a new normal anyway. ASN can no longer work with the business as usual model, but must change the mindset and pattern of action as an ASN that serves the community responsively, quickly, precisely and satisfactorily. This goes back to the effectiveness and efficiency of the work that is really needed in the current era of the COVID-19 pandemic. Therefore, widyaiswara must be a facilitator, motivator, inspiration, innovator, dynamicator and role model for all ASN to immerse this public service culture during the teaching and learning process through the concept of Corporate University, so that the quality of ASN will improve and can compete in the changing world today.

5. Flexible Working Space. Working in an office within regular and regular working hours is not a wise choice for ASN. The COVID-19 pandemic has created a new normal that allows individuals to limit themselves to physical interaction, so working at home is inevitability. Therefore, ASN business processes will be forced to change by relying more on information technology and effectiveness in working by no longer seeing routines and working hours in serving the community. In this condition, widyaiswara must be a facilitator, motivator, inspiration, innovator, dynamicator and role model.

Widyaiswara had to change himself to adjust to the current conditions. Various efforts, such as online learning, distance learning, effectiveness of learning management system (LMS) and other methods, are used to facilitate the teaching and learning process and adjust to this Flexible Working Space, with the main goal being to change the mindset and work pattern of ASN for the better. Widyaiswara must be able to change itself and 
mindset by always updating understanding and sharing knowledge by building networks as a means of sharing knowledge and experience and problems related to the development of ASN competencies and widyaiswara profession independently so that it can always be innovative and adaptive in the development of the world today.

\section{Conclusion}

The COVID-19 pandemic has impacted many aspects of human life. Not only impacting business activities, the COVID-19 pandemic also has an impact on the competency development model of ASN or Civil Servants (PNS) especially in the training path. Widyaiswara plays an important role in developing ASN competencies so that they must be able to educate and train ASN with constructive learning patterns in accordance with the development of the times and under any circumstances including during the COVID-19 pandemic. In training conducted through distance learning, widyaiswara is required to be able to think creatively and innovatively. The challenge is whether widyaiswara is able to make interesting multimedia teaching materials. To create multimedia learning media, widyaiswara must be familiar with shooting, animation, screen recording and editing process that takes not a little time, not to mention knowledge and insights related to devices or virtual learning media used by the organizers, such as zoom application, google meet, webex meet, and others. Therefore, it is no exaggeration to say that the biggest challenge of online training is actually on the shoulders of widyaiswara so that to face these challenges, widyaiswara must be improved and changed.

To answer the challenges and demands of change in the world of ASN, government bureaucracy and asn capacity building in this pandemic and new normal era, widyaiswara must be willing and able to change. Widyaiswara is a "nation teacher" who is required by professionals in managing the classroom, creating a fun learning atmosphere and can act as a facilitator, motivator, inspiration, innovator, dynamicator and role model through innovation and adaptation in the pandemic and new normal era through his roles in the aspects of bureaucracy efficiency, digital literacy, agile organization mindset, public service responsiveness, and integrated and flexible working space.

\section{Recommendation}

In the face of challenges in increasing asn capacity in pandemic and new normal, widyaiswara is required to improve through the use of smart and innovative ways. Widyaiswara should be able to utilize technology to open the horizon of thinking and view technology as an opportunity to improve ASN competence in the future.Competence is necessary for the successful and productive attainment of organization objectives (Mudiarsono, Sulaksana and Muljana, 2021). Thus, widyaiswara is expected not to get caught up in the routine of the organization but to be able to interpret every action as a form of major contribution to the changes of Indonesian civilization.

Some recommendations that can be given to answer challenges and provide an optimal role in the development of ASN competencies in pandemic and new normal are as follows:

1. The Ministry of Finance through BPPK is expected to increase the frequency of learning programs/trainings that have objectives and competency standards that can support insights, capacities and technical competencies for widyaiswara in the field of information technology and digital learning.

2. To support capacity building and technical competence through learning / training (regular), widyaiswara needs to increase its participation in sharing online webinars 
related to information and digital technology, both organized by BPPK (internal) and other institutions (external).

3. To support the recommendations (points 1 and 2) above, it is recommended that widyaiswara's role and participation in improving skills, knowledge, and attitude in the field of information technology and digital learning can be strengthened by setting it in the Main Performance Indicators (Indikator Kinerja Utama, IKU) widyaiswara.

4. The dominance of the influence and existence of technology on learning / training in terms of knowledge management and ministry of finance corpu in the future, demanding support and strengthening of the development and improvement of learning systems and media that have been built, among others by allocating adequate budgets and awarding awards (rewards) to employees who act as designers, builders, and managers of the system.

\section{References}

Adhikari, S. P., Meng, S., Wu, Y. J., Mao, Y. P., Ye, R. X., Wang, Q. Z., \& Zhou, H. (2020). Epidemiology, causes, clinical manifestation and diagnosis, prevention and control of coronavirus disease (COVID-19) during the early outbreak period: a scoping review. Infectious diseases of poverty, 9(1), 1-12.

Ahmed, N., Shakoor, M., Vohra, F., Abduljabbar, T., Mariam, Q., \& Rehman, M. A. (2020). Knowledge, awareness and practice of health care professionals amid SARSCoV-2, corona virus disease outbreak. Pakistan Journal of Medical Sciences, 36(COVID19-S4), S49.

AM, E. N., Affandi, A., Udobong, A., \& Sarwani, S. (2020). Implementation of Human Resource Management in the Adaptation Period for New Habits. International Journal of Educational Administration, Management, and Leadership, 19-26.

Balanzá-Martínez, V., Kapczinski, F., de Azevedo Cardoso, T., Atienza-Carbonell, B., Rosa, A. R., Mota, J. C., \& De Boni, R. B. (2021). The assessment of lifestyle changes during the COVID-19 pandemic using a multidimensional scale. Revista de psiquiatria y salud mental, 14(1), 16-26.

BPPK (Badan Pendidikan dan Pelatihan Keuangan). 2020. Majalah Edukasi Keuangan. 59,6 .

Carnevale, J. B., \& Hatak, I. (2020). Employee adjustment and well-being in the era of COVID-19: Implications for human resource management. Journal of Business Research, 116, 183-187.

Chen, Y., Sun, X., \& Jin, Y. (2019). Communication-efficient federated deep learning with layerwise asynchronous model update and temporally weighted aggregation. IEEE transactions on neural networks and learning systems, 31(10), 4229-4238.

Gunawan, S., Sasongko, R. N., \& Kristiawan, M. (2021). Widyaiswara Competence in Industrial Revolution 4.0 Toward Indonesia Unggul. International Journal of Multicultural and Multireligious Understanding, 8(4), 600-609.

Hamdi, M, \& Ismaryati, S. (2019). Materi Pokok Metodologi Penelitian Administrasi; 1 12; MAPU5103/4 SKS. Tangerang Selatan: Universitas Terbuka.

Hasyim, H. (2018). Implementation of organization culture by functional Widyaiswara on human resources development agency of South Sulawesi Province. MEC-J (Management and Economics Journal), 2(1), 23-38.

Iskandar, A., \& Subekan, A. (2020). Evaluating the Distance Learning in the Pandemic Era: A Case Study at Financial Education and Training Agency Makassar. Jurnal Pajar (Pendidikan dan Pengajaran), 4(6),1206-21. 
Jarkasih, A. (2021). The Influence of Bureaucracy Apparatus' Behaviour to Service Quality of Land Certificate (Study at the Land Office of Majalengka, West Java). Budapest International Research and Critics Institute-Journal (BIRCI-Journal), 4(2), 22862297.

John, W. C. (2013). Research Design Pendekatan Kualitatif, Kuantitatif dan Mixed. Yogyakarta: Pustaka Pelajar.

Jooss, S., McDonnell, A., \& Conroy, K. (2020). Flexible global working arrangements: An integrative review and future research agenda. Human Resource Management Review, 100780.

Kementerian Kelautan dan Perikanan (KKP). (2020). Tantangan Widyaiswara di Era New Normal. https://kkp.go.id/brsdm/bdasukamandi/artikel/21108-tantanganwidyaiswara-di-era-new-normal. Diakses pada tanggal 24 Februari 2021.

LAN. (2020). Jalan Menuju ASN Unggul Pasca Pandemi. https://lan.go.id/?p=2523. Diakses pada tanggal 24 Februari 2021.

Mudiarsono, Sulaksana, N., and Muljana, B. (2021). The Influence of Open Selection and Official Competence in Filling Primary High Leadership Positions on the Organizational Performance of Regional Apparatus in East Belitung Regency. Budapest International Research and Critics Institute-Journal (BIRCI-Journal), 4(2), 1894-1902.

Narayana, I.W.G. (2016). Analisis Terhadap Hasil Penggunaan Metode Pembelajaran Synchronous dan Asynchronous. Semnasteknomedia Online, 4(1):1-4.

Nugroho, Y. A. (2020). Distance Learning, Widyaiswara Dituntut Kreatif dan Inovatif. https://lan.go.id/?p=2514. Accessed on 24 February 2021.

Salam, R. (2021). The Implementation of Good Governance with a View to Improving the Competence of State Civil Apparatus in the Regional Government. Budapest International Research and Critics Institute-Journal (BIRCI-Journal), 4(1), 11981206.

Sarwono, J. (2006). Metode Penelitian Kuantitatif dan Kualitatif. Graha Ilmu.

Sulaksono, A., Astuti, E. S., \& Almusadieq, M. (2020). Strengthening Website Usability in the Pandemic Era. In 2nd Annual International Conference on Business and Public Administration (AICoBPA 2019) (pp. 272-277). Atlantis Press.

Surat Edaran (SE) Menteri Pendayagunaan Aparatur Negara dan Reformasi Birokrasi (Menpan-RB) Nomor 58/220 tentang Sistem Kerja Pegawai ASN dalam Tatanan Normal Baru.

Tribun-News. (2020). Menteri Tjahjo: Widyaiswara Harus Adaptif dengan Perubahan di Saat Pandemi. https://m.tribunnews.com/nasional/2020/09/19/menteri-tjahjowidyaiswara-harus-adaptif-dengan-perubahan-di-saat-pandemi?page=all. Accessed on 24 February 2021. 